\title{
Manichaean Books: Literary Texts and Textual Community
}

You do not lack anything from [the] mysteries of the wisdom of God. Much is [... the] wisdom that I have proclaimed to [...], that which I have written [for] you in [my holy books?]. You do [not lack] anything from the wisdom. There is only this one thing: devote yourself to what is written.

P.Kellis vi Copt. $54,11.12-17$

The above citation is taken from a letter fragment discovered in House 3 , alongside the other documentary papyri of the Pamour family. It is clearly a very different type of letter than those of Pamour III, Pekysis, or even Makarios, however, and should probably be assigned to one of Mani's 'canonical' letters, deriving from a small collection of his Epistles of which a few codex leafs have been discovered in House 1-3. It demonstrates the importance of the written word, and not least of the books he produced, to Mani's sense of mission and self-conception. Yet, the importance of Manichean texts, even those of Mani, to his lay followers has been a matter of some controversy among scholars. The present chapter examines the remains of the Epistles, as well as other Manichaean literary texts from House $1-3$, in order to illuminate this question and integrate them into the analysis of religious practice and identity at Kellis.

The investigation is conducted in two steps. First, we continue the discussion from Chapter 5 concerning the 'Manichaeanness' of lay identity at Kellis, now looking at what the literary papyri tell us. It was argued in that chapter that the documentary letters contain cues that indicate the authors' participation in a consciously Manichaean community. Yet it was also seen that, apart from some notable exceptions, most of these cues do not draw on specifically Manichaean myths or concepts, which has been taken to imply an absence of a distinctive 'Manichaeanness' among the laity. Scholars have taken the literary texts to point in the same direction. It has been proposed (although not argued in extensio) that the literary finds indicate that Manichaean ideas were of little interest to or even unknown to the people of House 1-3, supporting a depiction of the laity as adhering to a 'superior Christianity' rather than what is taken to be 'Manichaeism proper'. The current chapter examines these texts in order to consider the presence or absence of Manichaean ideas more closely. 
Second, and in extension of this, we examine the role texts played in the reproduction of identity among the laity. In and of itself, the presence of Manichaean ideas in these texts is not sufficient to establish that they were appropriated by the laity. Rather, we have to grasp how the literary texts functioned - what they did - in the network. How were religious texts used? And how did the interplay between texts and practices impact the shared religious identity discussed previously? The second part of this chapter employs the concept of textual community in order to shed light on these issues, and examines the textual practices in which the literary papyri were embedded, as attested to by both the documentary and the literary papyri themselves.

\section{$1 \quad$ A Manichaean World}

Literary texts were widely dispersed among the other papyri found at House 1-3. ${ }^{1}$ Texts were found both in Greek and Coptic. In addition, bilingual lists with religious vocabulary have also been found, such as the Syriac-to-Coptic and Syriac-to-Greek translations of, or tools for translating, religious texts (T.Kellis II Syr./Copt. 1, 2; P.Kellis II Syr./Gr. 1). These are not treated here, but are important evidence for the translation of Manichaean texts from Syriac and directly into Coptic by non-Syriac speakers. ${ }^{2}$ Not all the literary texts were religious - as the find of a codex with speeches by the Athenian rhetor Isocrates in House 2 shows, - but the vast majority were. They consisted of psalm collections, prayers, literary 'epistles', and other works. What do they tell us about the nature of the community that utilised them? Gardner posed this question in the first volume of literary papyri from House $1-3 .{ }^{3}$ He noted the prevalence of devotional material, such as hymns and prayers, which - in conjunction with the documentary and archaeological remains - provided the basis for identifying the community as composed of Auditors. These Auditors were, in Gardner's view, characterised by little engagement with the more

1 The term 'literary' is certainly not unproblematic, and the distinction literary - documentary must be seen as fleeting. For the purpose of my analysis here, I exclude the astrological calendars, horoscopes, and magical invocations published in P.Kellis I (Gr. 82-90), although constituting important evidence for magical practices side-by-side (and perhaps integrated) with Manichaean ones, for which see Chapter 8, Section 3.4. For similar material (mostly) from other parts of Kellis, see de Jong and Worp, 'A Greek Horoscope'; de Jong and Worp, 'More Greek Horoscopes'; and Worp, 'Miscellaneous New Papyri'.

2 Franzmann, 'Syriac-Coptic Bilinguals'.

3 P.Kellis II, vi. 
intricate teachings of Mani, and he proposed that the literary texts indicate that they primarily saw their religiosity as a higher form of Christianity:

The amazing detail of Mani's teachings as regards the various worlds of gods and demons, although a feature emphasized by the heresiologists for polemical purposes, would seem in some senses to have been restricted knowledge into which the elect might only gradually draw the convert. The concerns of the mass of believers were necessarily more matter-of-fact, for whom Manichaeism would have been a kind of higher and more effective Christianity. ${ }^{4}$

He furthermore maintained that the discovery of fragments of codices containing Mani's Epistles supported the reconstruction of a group whose members were primarily oriented towards ethical and practical concerns, and Christian Gospel exegesis - they 'evidence little interest in (and perhaps knowledge of) the fantastic worlds described in a text such as the Kephalaia. ${ }^{5}$ In the introduction to P.Kellis VI, he again stressed that the texts evince 'a vibrant faith focused on praise and conversion. ${ }^{6}$ Assessment of the evidence along these lines were also put forward elsewhere. In their important collection of Manichaean texts from the Roman Empire in translation, Gardner and Lieu asserted that:

For the lay faithful in the Roman Empire it was a kind of superior Christianity, and the metaphysical details that attract the attention of scholars (and the higher echelons of the elect) had little profile.... The textual material derived from Kellis (modern Ismant el-Kharab) evidences how carefully the hierarchy attempted to draw adherents further into the church and the knowledge of truth. ${ }^{7}$

The view that the laity at Kellis were in some sense shielded from 'proper' Manichaean teachings, and that 'pure' Manichaean doctrines were only imparted to lay people through gradual (individual?) initiation, or reserved for the Elect, has been accepted by many scholars. ${ }^{8}$

4 Ibid., ix-x.

5 Ibid., $\mathrm{x}$.

6 P.Kellis VI, 6.

7 Gardner and Lieu, Manichaean Texts, 9 .

8 See e.g. Nongbri, Before Religion, 72; Pettipiece, 'Rhetorica Manichaica'; and Gábor Kósa, 'The Protagonist-Catalogues of the Apocryphal Acts of Apostles in the Coptic Manichaica A Re-Assessment of the Evidence', in From Illahun to Djeme. Papers Presented in Honour of Ulrich Luft, ed. Eszter Bechtold, András Gulyás, and Andrea Hasznos (Oxford: Archaeopress, 2011), 113 . 
One problem with this depiction is that there has, as of yet, not been any attempts to define exactly what is meant by such 'metaphysical details'. Presumably, they include the diverse lists of emanations, detailed mythological drama, and intricate workings of demonic and divine forces in human bodies, found in the Kephalaia literature. But Manichaean metaphysics entailed much more central ideas that also depart drastically from mainstream (and, in some cases, non-mainstream) currents of Christian thought. They include:

- The central conflict between two primeval principles.

- The existence of a world soul divided and dispersed in all living beings, and its imprisonment through transmigration.

- The ability of conditioned human bodies to liberate souls (both their own and others').

- Liberated souls' ascent through the natural world, through the workings of divine forces such as the sun and the moon.

- Mani's role as the founder of a new 'Church' through which salvation is achieved.

It is not clear from previous scholarly literature whether (or which of) these ideas are to be considered among the 'metaphysical details' of the Elect, or the 'superior Christianity' of the laity.

Rather than seeing these ideas as part of a superior Christianity, we shall here propose to conceptualise them as key 'Manichaean notions', a set of ideas that together constituted a specifically 'Manichaean world'. Individually, most of them (bar the last) can be found in other religious or philosophical traditions, including other Christian frameworks of worship. Where all are present, however, they shaped a distinctively Manichaean world-view: one that made Manichaean rituals 'work' in the cosmos, constituting the logic that underpinned Elect practice. If they were indeed disseminated among the laity, those adherents who chose to appropriate them could use them as justifications (or rationales) for the Manichaean institutions in which they were asked to participate, a point to which we return towards the end of this chapter. ${ }^{9}$ While we should be careful not to privilege ideas over practice, as anthropologists and scholars of religion have long recognised, and while it is true that we cannot know whether 'belief' was present in the minds of specific individuals at Kellis, shared ideas cannot be neglected completely when considering religious identity. ${ }^{10}$

$9 \quad$ For the concept of justifications, see Berger and Luckmann, Social Construction, 110-22; for rationales as employed in the context of Manichaeism, see BeDuhn, The Manichaean Body, 22-23.

10 For the traditional criticism of 'belief', see e.g. McGuire, Lived Religion, 39-44. For recent trends, which have seen a resurgence of interest in the topic, see Bosco B. Bae, 'Believing 
We start by treating the various types of literary texts found in House 1-3, presenting their content and evaluating their engagement with Manichaean ideas. We survey the contents of the psalms, the prayers, and the Epistles, examining the way they present the notions of 'dualism', divine emanations, the imprisoned world soul, the ascent of individual souls, and the role of Mani and his Church.11

\section{Manichaean Literature}

2.1

The Psalms

The main body of religious texts retrieved from House 1-3 were psalms and prayers. Psalms formed an important component of Manichaean ritual practice and literary works, often sung at church gatherings and festivals. Mani himself composed Psalms and Prayers for the community, which were counted among his canonical books - usually together, as a single work, ${ }^{12}$ although they could be separated: in one passage from a Medinet Madi psalm, Mani's works are likened to different remedies, the two last being: '[...] that is hot, the two Psalms, the weeping [...] there is a cure also that is cool, his Prayers and all his lessons'. ${ }^{13}$ This passage, moreover, indicates that Mani wrote two Psalms. Their contents have long been unknown, ${ }^{14}$ but recent work has provided new insight. A body of psalms from Turfan, reconstructed from multiple manuscripts and languages, does in fact include two psalms ascribed to Mani, called The Praise of the Small Ones and The Praise of the Great Ones. ${ }^{15}$ That these are Mani's own Psalms may be supported by the identification of a prayer that accompanied them with the so-called 'daily-prayer', also attributable to him (see below).

For the most part, the psalms found at Kellis were not authored by Mani. ${ }^{16}$ They belong to the later body of literary productions found in the Psalm-book from Medinet Madi: several Kellis psalms can be identified with counterparts

Selves and Cognitive Dissonance: Connecting Individual and Society via "Belief", in Religions 20167 no. 7 .

11 The division between psalms and prayers here is for organisational purposes; the boundaries between these categories may have been fluid.

12 Gardner and Lieu, Manichaean Texts, 153.

132 Ps. 47.3-4, trans. Gardner and Lieu, Manichaean Texts, 164.

14 Gardner and Lieu, Manichaean Texts, 163-64.

15 Desmond Durkin-Meisterernst and Enrico Morano, eds., Mani's Psalms. Middle Persian, Parthian and Sogdian Texts in the Turfan Collection (Turnhout: Brepols, 2010).

16 Exceptions may be P.Kellis I Gr. 91 and 92, where echoes of Mani's The Praise of the Great Ones are in evidence, as noted by Mattias Brand in his forthcoming study of Manichaean songs, which he has kindly shared. See Mattias Brand, 'Making Manicheism Real: Group 
in this codex. With its 672 pages, the Psalm-book is the largest known ancient papyrus codex, although it was split into two parts (1 Ps and 2 Ps) in modern times. ${ }^{17}$ It contained a large body of psalms, numbering at least 362 , subdivided into different psalm groups composed by different authors and for different occasions; compiled, edited, and translated into Coptic from Syriac and/or Greek. ${ }^{18}$ It included psalm groups intended for specific ritual gatherings, such as Sunday Psalms. ${ }^{19}$

Turning to the Kellis texts, about 23 texts in Coptic and two in Greek have been identified as psalms; about half of these are contained in the remains of two codices, T.Kellis II Copt. 2 and P.Kellis II Copt. 2. Many are very fragmented, and the six or so psalms in T.Kellis II Copt. 2 are all abbreviated (giving only the first lines of each stanza), so the number whose contents can be made out is lower. Still, Gardner identified six of the psalms from the Kellis corpus with psalms known from the Medinet Madi Psalm-book. ${ }^{20} \mathrm{~A}$ further identification was later made by Gregor Wurst. ${ }^{21}$ The Kellis psalms are local products, copied up by adherents in Kellis for their own liturgical needs, unlike the edited compendium of the Medinet Madi codex. For the psalms in T.Kellis II Copt. 2, a folio-board from a wooden codex, only the first words of each strophe were written out, suggesting that they were used as memory-aides for singers who already knew the texts. ${ }^{22}$ While text A2 is paralleled by Medinet Madi Psalm 68, Gardner noted an impression 'that the Kellis text is a more fluid and oral rendition', which 'reinforces the sense of the overall structure of T. Kell.

Formation through Song', in Resonant Faith in Late Antiquity, ed. Arkadiy Avdokhin (London: Routledge, forthcoming).

17 Only the second has been translated and published. A facsimile edition of 1 Ps was published by Søren Giversen in 1988. For more recent work, see Richter, 'Arbeiten'.

18 Of these, 289 were enumerated, in turn edited together with several other collections. For its editorial history, see Allberry, Psalm-Book, xix; Wurst, Die Bêma-Psalmen, 1-4; Richter, Die Herakleides-Psalmen, $1-7$.

19 Gregor Wurst, 'Die Bedeutung der manichäischen Sonntagsfeier (Manichäischen Psalmenbuch I, 127)'. In Ägypten und Nubien in spätantiker und christlicher Zeit, ed. Stephen Emmel, Martin Krause, Siegfried G. Richter, and Sofia Schaten (Wiesbaden: Reichert Verlag, 1999).

20 T.Kellis II Copt. 2 A2 (Psalm 68), 4a (Psalm 222), 4b (Psalm 108), 6 (Psalm 261), P.Kellis II Copt. $1 \mathrm{~A}$ (Psalm 246), and $2 \mathrm{Cl}$ (1 Ps 277-78). Of these, Psalms 222, 246, and 261 are found in 2 Ps, published by Allberry, while Gardner included transcriptions and translations from Giversen's facsimile-edition of 1 Ps in his extensive apparatus for Psalms 68, 108, and the unsorted and unnumbered leafs $277-278$. See P.Kellis II, 18-24, 33, 42, 55, 64-72.

21 Wurst showed that P.Kellis II Copt. $2 \mathrm{C} 2$ parallels Psalm 126, also from 1 Ps., as noted in P.Kellis VI, 173 .

22 Gardner notes that similar texts are known from Central Asian material. P.Kellis II, 9 n.57. 
Copt. 2 as a subsidiary document; and derived from an "authorised" version. ${ }^{23}$ Not all of them were, perhaps, intended for singing. For P.Kellis II Copt. 1, a codex leaf with two psalms, Gardner described its production as coarse, notes that the pieces 'are best termed a "scrap-book" of Manichaean Psalms', and comments:

I suggest that it is the product of local catechumens, probably family members living in House 3, who undertook to copy out psalms as part of their spiritual praxis. Such are the evident errors that it can hardly be regarded as a professional production; and it is also doubtful whether it was actually used for liturgy. ${ }^{24}$

He further proposed that the Kellis texts pertained to a second stage of redactional work, after an initial stage of translation from Greek and Syriac (likely in Middle Egypt), but predating 'at least the latter parts of the process that gave the Medinet Madi codex its distinctive form.'25 Yet the Kellis texts, too, were probably drawn from an authoritative collection, as indicated for T.Kellis II Copt. 2 (above), even if the logic behind their selection is unclear.

Much remains to be done with regards to the relationship between Ismant el-Kharab and Medinet Madi. For present purposes, the Kellis texts are close enough to the Medinet Madi versions for the latter (when preserved) to be used to examine the contents of the former, although potential changes during transmission should be kept in mind. In total, about ten psalms from Kellis are wholly preserved, preserved in large parts, and/or identifiable with Medinet Madi texts. ${ }^{26}$ They form the basis of the analysis below.

\subsubsection{Manichaean Notions in the Kellis Psalms}

Many of the psalms are addressed to the soul, or take the perspective of the soul. The psalms in T.Kellis II Copt. 2 shift between addressing the soul (esp. $\mathrm{A}_{2}, \mathrm{~A}_{3}, \mathrm{~A}_{4}$ ) and taking the soul's or the singers' perspective, addressing divinities. Christ plays a prominent role and recurs frequently. Paul, too, occurs in A2, and is cited in the text (I Cor. 3.19). But Manichaean notions also abound, and can be found in all the texts of which more substantial parts are preserved.

\footnotetext{
23 Ibid., 24 .

24 Ibid., 59 .

25 Ibid., xv.

26 T.Kellis II Copt. 2A2, 4a, 6, 7; P.Kellis II Copt. 1A, 1B, 2B, 2 C1; P.Kellis II Gr. 92; P.Kellis vi Gr. 97 B.I.
} 
Regarding the fundamental duality of the two principles, it is not expressed explicitly in the preserved psalms. It is, however, taken for granted, and both forces are depicted. In particular, a wide array of Light divinities occur, associated with the Land of Light and presided over by the hidden Father of the Lights with his Aeons. ${ }^{27}$ P.Kellis II Gr. 92 even contains a hymn to 'the foundation of the Lights', the 'hidden', and 'self-constituting' Father, i.e. to the chief god of the Manichaean pantheon himself. Although of course the ultimate source of all divinity and goodness, he is a distant figure, and, one might assume, unlikely to attract everyday worship, so the appearance of a hymn to him is of some note. While demonic Matter and her sons do occur (e.g. T.Kellis II Copt. 1A), they receive less attention.

The primeval war between them, and the establishment of the world, is presented in some detail. Several texts refer to the descent of the Light into Darkness as part of a stratagem to defeat it. ${ }^{28}$ Divinities engaged with this struggle occur in a wide variety of psalms. ${ }^{29}$ P.Kellis vi Gr. 97 B.I is of particular note. The psalm as preserved here is dedicated to a female personification of the descending cosmic Soul, and features (other) striking details: the name of the obscure 'Beloved of the Lights' is preserved, as is parts of a list of the five 'Sons of the Living Spirit' who guard the cosmos, each with his 'canonical' virtue, ${ }^{30}$ and the rare mytheme of the emergence of a boundary to separate Light from Darkness after the battle: 'a wall for the aeons of light established itself' $(11.4-5 \mathrm{r})$.

While 'cosmic' mythemes are in evidence, the psalms more often treat the Light in its imprisoned state. Several refer to the kinship between individual souls, the suffering world soul, and the gods: either through direct claims of kinship, or through depictions of the five Light Elements that constitute the world soul, and identifying their tribulations with that of the individual soul. ${ }^{31}$ The Medinet Madi Psalm 246, parts of which are preserved in P.Kellis II Copt. $1 \mathrm{~A}$, gives an evocative depiction of the world soul's suffering, how it has been divided and spread out in the material world:

27 P.Kellis II Copt. 1A and 1B; P.Kellis II Gr. 92; P.Kellis vi Gr. 97B.I.

28 P.Kellis II Copt. 1A and 1B; P.Kellis II Gr. 97B.I.

29 Such as the Mother of Life (P.Kellis II Copt. 1B, P.Kellis II Gr. 92), the First Man (P.Kellis II Copt. $1 \mathrm{~A},{ }_{2} \mathrm{C1}$ ), the Beloved of the Lights (P.Kellis vi Gr. 97B.I), and the five 'Sons of the Living Spirit' (the 'Porters') (T.Kellis II Copt. 7; P.Kellis vi Gr. 97B.I).

30 They were, in order of importance: the Keeper of Splendour, the King of Honour, the Adamas of Light, the King of Glory, and the Omophoros (Atlas). Unfortunately, only the name of the King of Honour and two 'virtues' are preserved ('great thought', associated with the King of Honour, and 'great insight', with the Adamas).

31 For claims of kinship, see P.Kellis II Copt. $1 \mathrm{~A},{ }_{2} \mathrm{C}$; for references to the Elements, see T.Kellis II Copt. 7; P.Kellis II Copt. 1A, 1B, P.Kellis vi Gr. 97B.I. 
Matter and her sons divided me ... I am in everything, I bear the skies, I am the foundation, I support the earths, I am the Light that shines forth, that gives joy to souls. I am the life of the world: I am the milk that is in all trees: I am the sweet water that is beneath the sons of Matter

2 Ps. 54.17-30, abridged

Even the 'canonical' sequence of Elements (i.e. air, wind, light, water, and fire), is preserved in P.Kellis II Copt. 1B. The nefarious demonic forces and their activities in human bodies are also in evidence. ${ }^{32}$ The Medinet Madi Psalm partly preserved in T.Kellis II Copt. 2A2, Psalm 68, dwells particularly on this topic:

A depth of darkness is this body that you (m.sg.) wear [...] all the righteous, they have suffered, [they have ...] been oppressed in it. The creature of darkness is this house of passion [...] these masses of flesh, these beasts that [...] It is a many-faced demon, a seven-[headed] dragon. It is many likenesses, many wickednesses, a place [...] The work of perdition is the garment of [darkness that we wear ...] they bound with (?) [...]'

1 Ps. 97.13-22, trans. GARDNER

In the Medinet Madi version, the last fragmented line of this stanza alludes to the demonic creation of the body, while the one that follows alludes to its associated sins (1 Ps. 97.23-25). P.Kellis II Copt. 2B even features an example of an irredeemably evil creature: scorpions. ${ }^{33}$

The most common theme, however, is that of the release and ascent of the soul. Here, too, the psalms evince extensive familiarity with distinctly Manichaean details tied to this process. These include divine entities that the soul receives upon its release from bondage, such as the Diadem of Light or 'crown', and the soul's vision of its own 'image' or 'form. ${ }^{34}$ There are several references to the role of the Sun and the Moon: 'Ships of Light' or 'Towers' to which souls ascend. ${ }^{35}$ The workings of the 'sphere' that played a part in releasing Light particles from the earth, and their ascent through the atmosphere,

32 T.Kellis II Copt. 2A2, 7; P.Kellis II Copt. 1A, 2 C1.

33 The scorpion was apparently a favourite example of a creature of pure evil among the Manichaeans; cp. De mor. 2.8.11. Perhaps the famous parable of the scorpion and the turtle influenced this choice.

34 T.Kellis II Copt. 2A4, 2C1; P.Kellis II Copt. 1A.

35 For 'Ships of Light', see T.Kellis II Copt. 6, P.Kellis II Copt. 1A; for 'Towers', see T.Kellis II Copt. 7 . 
are found.$^{36}$ It is captured in a striking image in P.Kellis II Copt. $1 \mathrm{Al}$, describing how the cosmos releases Light: 'the Sphere turns quickly, while the lights purify [the life]' (ll.6-8). ${ }^{37}$ The Perfect Man, the end-time 'statue' in which individual souls merge for transport to the Land of Light, occurs in T.Kellis II Copt. 7 .

Finally, the psalms evince knowledge of central aspects of the church community. Mani is mentioned, both by name and in his capacity as Paraclete. His Gospel, from 'alpha [to omega]', is praised in T.Kellis II Copt. 7 (l.42). ${ }^{38} \mathrm{He}$ himself was probably the addressee of, and his torture and death are alluded to in preserved parts of, some of the abbreviated psalms. ${ }^{39}$ The Church is several times referred to as 'the Church of the Paraclete. ${ }^{40}$ The Paraclete is its founder, the one who 'planted has the Tree of Knowledge' in the Holy Church as it is expressed in Psalm 261 (2 Ps 75.30), partly preserved in T.Kellis II Copt. 6. The same psalm refers to the Elect as 'Elect of God', and describes them as 'ministers of God who are in the Church' (2 Ps 75.28-29). A Bema-Psalm, Psalm 222, is partly preserved in T.Kellis II Copt. 4 a ; it evinces knowledge of both the festival itself and the associated practice of confession, as well as the (to us) more obscure 'greeting of the right hand' and its mythical backdrop. ${ }^{41}$

\subsection{The Prayers}

Six texts from Kellis have been labelled 'prayers' by their editors. Of these, one is in Coptic and five are in Greek. ${ }^{42}$ Three of the Greek texts are rather short or incomplete. ${ }^{43}$ In the following, we focus on three more substantial texts; P.Kellis II Copt. 2A5, P.Kellis VI Gr. 98, and P.Kellis II Gr. 91, each considered separately. P.Kellis vi Gr. 98 is of particular interest, as this prayer can be identified as a work of Mani himself, the so-called 'daily prayer', as we shall see below.

36 The atmosphere, T.Kellis II Copt. $2 \mathrm{C}$; for the sphere, T.Kellis II Copt. 4a; P.Kellis II Copt. 1A.

37 Allberry's reconstruction of the Medinet Madi Psalm 246 on this point (2 Ps. 55.7-8) must thus be amended.

38 See also T.Kellis II Copt. 4a.

39 For Mani as addressee, see perhaps T.Kellis II Copt. $2 \mathrm{~B} 2$; for his death, T.Kellis II Copt. $2 \mathrm{Al}$ (and perhaps 2A4).

40 T.Kellis II Copt. 2A2, 4a, 6.

41 T.Kellis II Copt. 2A3, P.Kellis vi Gr. 97B.I.

42 Coptic: T.Kellis II Copt. 2A4; Greek: P.Kellis I Gr. 88; P.Kellis II Gr. 91, 93(?), 94; P.Kellis vI Gr. 98.

43 P.Kellis II Gr. 93 is very fragmented, P.Kellis I Gr. 88 is a short invocation on a wooden board, and P.Kellis II Gr. 94 is again a short text on a board, praising the Great Father of Lights (Gonis and Römer, 'Ein Lobgesang'). 


\subsubsection{A Prayer for the Soul's Ascent: T.Kellis II Copt. 2 A5}

First, another remarkable prayer is found in text $\mathrm{A}_{5}$ from the wooden codex T.Kellis II Copt. 2 (which also contained six or more abbreviated psalms, see above). The prayer is written from the point of view of a deceased soul, which invokes a series of Manichaean divinities before and during its ascent to the Land of Light. It starts with an appeal to the Third Ambassador, then Jesus the

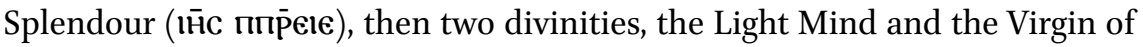

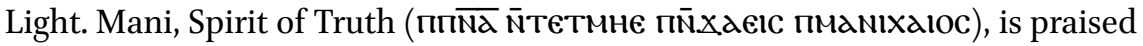
for having bestowed his knowledge upon the speaker, strengthened the soul in his faith, and completed it by his commandments. These divinities are all linked to the descent of Light into the world for the salvation of human beings, and are listed by order of emanation in the 'canonical' scheme known from other Manichaean sources. ${ }^{44}$ Next appears the soul's counterpart (ncalc)) with three angels, and present it with gifts that symbolise victory over death. The soul starts to ascend, meeting the Judge, being washed in the Pillar, and becoming perfected in the Perfect Man - i.e. restored as fleshless and sinless and joined to other ascending souls. The judge is the so-called 'Judge in the Air' known from other Manichaean sources, indicating that the soul's journey takes place in the physical world ${ }^{45}$ It rises to the 'ship of living water' (חxdel MпmaoY ETdN2), i.e. the moon, where the First Man blesses it, and then to the sun (пхגєı N̄тсєтє єтамq) where the Third Ambassador is located. From there it is ferried to the Land of Light, where the 'first righteous one' and the Beloved of the Lights are. Finally, in a passage that may look ahead to the end-times, the Father of the Lights reveals his image. ${ }^{46}$

Gardner notes that the terms echo those found in the Berlin Kephalaia, and that the depiction of redemption is consonant with that found elsewhere - indeed, it 'remained remarkably constant across the Manichaean world. ${ }^{47}$ Certainly, the prayer is an elegant presentation of Manichaean soteriology. The psalms contained in the same codex similarly deal with the ascent of the soul (see $\mathrm{A} 4$, in particular), perhaps suggesting that the prayer was chosen to accompany a cycle of worship especially concerned with this theme. Gardner suggests that it was used 'to reinforce the faith in the face of death'. ${ }^{48}$

44 Jesus Splendour was an emanation of the Ambassador, the Light Mind (and the Virgin) of Jesus Splendour, and Mani (in his spiritual union with the Paraclete) of the Light Mind. See below.

45 E.g. keph. 28, where the Judge in the Air 'separates the righteous from the sinners' (1 Ke. 80.32). See also Lindt, Mythological Figures, 192-93.

46 As Gardner points out, it is probably a poetical anticipation of this event, see P.Kellis II, 26.

47 Ibid., 25 .

48 Ibid. 
But the prayer's usage needs further comment. It has recently been argued that the text was used as part of an Elect initiatory ritual. ${ }^{49}$ Certainly, it could be that the speaker is an Elect: the perfection and release achieved by the soul is often seen as reserved for them. If so, we should perhaps see this piece (and the entire codex?) as an Elect preserve, not used by the laity. On the other hand, Auditors were exhorted to emulate Elect behaviour, and would eventually reach the same destination. Although Auditors in general needed to be reincarnated as Elect before achieving salvation, chapter 91 of the Berlin Kephalaia even explains how perfectly behaved Auditors can still be released 'in one body', i.e. without needing to reincarnate (1 Ke. 228.20-229.20). It is at any rate unlikely that knowledge of this salvation, to which everyone should aspire, would have been kept hidden from them. There is no barrier to the prayer being recited by an Auditor - or a group of Auditors in unison, in keeping with the probable liturgical function of the codex.

2.2 .2

The Daily Prayer: P.Kellis vi Gr. 98 or 'The Prayer of the Emanations'

A wooden board found in the rear courtyard of House 3 contained a well-preserved text entitled 'Prayer of the emanations' (Eủxỳ $\tau \hat{\omega} v \pi \rho \circ \beta \circ \lambda \hat{\omega} v$ ), published as P.Kellis VI Gr. 98. Gardner remarks that 'in production, format and handwriting, this piece is generally superior to contemporary papyrus prayers. ${ }^{50}$ It is among the most significant finds of Manichaean literature from Kellis: a Greek translation of a work that can be ascribed to Mani. Even so, the text largely lacks specialised Manichaean (or Christian) terminology. Its Manichaean provenance was therefore questioned by Alexander Khosroyev, who argued that it should rather be seen as a pre-Christian gnostic text. ${ }^{51}$ However, a Manichaean background was maintained by Gardner, supported by Fernando Bermejo-Rubio. ${ }^{52}$

Shortly after having published this text in P.Kellis VI, Gardner discovered that it could be identified with a prayer appended to the end of the Praise of the Small Ones, part of a psalm cycle from Turfan being edited by Desmond

49 So, for instance, see Julia Iwersen, 'A Manichaean Ritual of Ascent? A Discussion of T. Kell. Copt. 2 A 5', in Zur lichten Heimat: Studien zu Manichäismus, Iranistik und Zentralasienkunde im Gedenken an Werner Sundermann., ed. Team Turfanforschung (Wiesbaden: Harrassowitz, 2017).

5o P.Kellis VI, 111 .

51 Alexander Khosroyev, 'Zu einem manichäischen (?) Gebet', in Il Manicheismo. Nuove prospettive della ricera, ed. Alois van Tongerloo and Luigi Cirillo (Turnhout: Brepols, 2005).

52 P.Kellis VI, 112-15; Fernando Bermejo-Rubio, 'Further Remarks on the Manichaean Nature

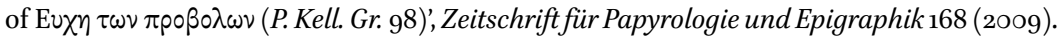


Durkin-Meisterernst and Enrico Morano. ${ }^{53}$ Furthermore, it could also be identified with a prayer described by al-Nadim, who attributed it to Mani himself. ${ }^{54}$ This prayer was to be prayed daily - four times a day by Auditors and seven by the Elect, according to al-Nadim - and is therefore known as the Daily prayer. Adherents washed themselves, turned towards the sun during the day and the moon at night, and prostrated themselves while praying. Al-Nadim described it as consisting of twelve (sub-)prayers and prostrations, and gives the text of the six first of these. For the Roman era, the prayer was previously known from remarks by Augustine, and an allusion to it has since also been found in the Kephalaia (1 Ke. 376.22-29). ${ }^{55}$ The complete text, however, is only found at Kellis. Admittedly, it only contains ten of the twelve verses mentioned by al-Nadim. As Gardner points out, this is likely to be explained by the fact while verse three to twelve are directed at various divinities, the two first verses given by al-Nadim are made in Mani's honour, and so not originally part of the prayer. The Kellis text preserves only the ten verses written by Mani. Each starts with

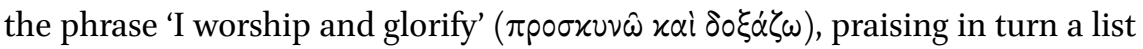
of divinities. These are:

1. The Father of Lights, who has perfected the 'foundation' ( $\sigma \dot{\sigma} \sigma \tau \alpha \sigma i v)$ of the

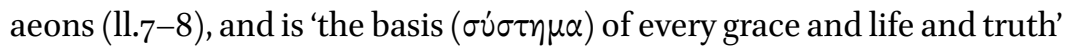
(1l.13-14).

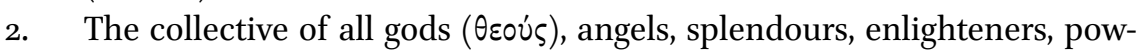
ers, all of whom 'subsist in holiness, and by his light are nourished, being purified of all darkness and malignance' (ll.19-22).

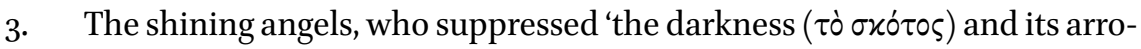
gant powers that were desiring to make war with the one who is first of all' (ll.26-29). They ordered the world and bound in it the 'foundation ( $\sigma \dot{\sigma} \sigma \alpha \sigma i v)$ of contempt' (ll.32-33).

4. 'The shining mind, king, Christ' (ll.34-35), who came from the aeons and interpreted the mysteries, separating truth from lie, light from darkness, good from evil, righteous from the wicked, on behalf of all races and in all languages.

5. The Living God, who 'raised up all things, what is ordered above and below' (1l.57-59).

53 Now published. See Durkin-Meisterernst and Morano, Mani's Psalms, xvii.

54 Iain Gardner, 'Manichaean Ritual Practice'; “'With a Pure Heart and a Truthful Tongue”: The Recovery of the Text of the Manichaean Daily Prayers', Journal of Late Antiquity 4, no. 1 (2011).

55 Gardner, “'With a Pure Heart", $85^{-86 .}$ 
6. The light givers, 'both the sun and the moon and the virtuous powers in them, which by wisdom conquer the antagonists and illuminate the entire order, and of all oversee and judge the world, and conduct the victorious among the souls into the great aeon of light' (1l.6o-69).

7. The five great lights $(\tau \dot{\alpha} \mu \varepsilon \gamma \dot{\alpha} \lambda \alpha \pi \dot{\varepsilon} v \tau \varepsilon \varphi \hat{\omega} \tau \alpha)$, 'through which by participation power and beauty and soul and life are found in all' (1l.73-75).

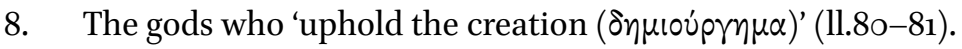

9. The shining angels who rule the universe, subdue demons, and protect righteousness.

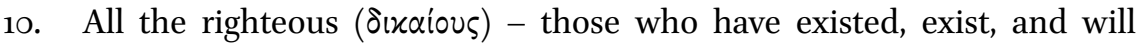
exist - 'in order that all the ones whom I have worshipped and glorified and named may help me and bless me with favour, and release me from every fetter and all compulsion and torment and reincarnation ( $\mu \varepsilon \tau \varepsilon v \sigma \omega-$ $\left.\mu \alpha \tau \omega^{\prime} \sigma \varepsilon \omega \nu\right)$ and grant me access into the great aeon of light' (1l.103-113).

This summary suffices to show that the prayer contains a compressed presentation of the whole Manichaean mythical scheme most relevant to the individual: from the mixing of Light and Darkness until the soul's ascension to the 'great aeon of light'. Admittedly, the emphasis is on the positive, divine powers that regulate the earth and liberate its souls, while the powers of darkness receive little attention. It might, then, be taken to downplay the characteristic Manichaean dualism. But as Bermejo-Rubio has pointed out, the text does posit an opposition between two radically different 'foundations' (both termed systasis), each with associated 'powers'. ${ }^{6}$ To be sure, it depicts an 'asymmetrical dualism', in which the Light is regarded as superior and in some sense prior, but this is common for Manichaean texts. ${ }^{57}$ Light divinities are described as 'gods' and as emanations from the Father. The Light (in the world) needs to be purified and separated from the Darkness, and so the divinities construct the world out of Darkness, keep evil in check, and descend to save souls. A long passage on 'the shining mind, king, Christ' may allude to, or perhaps prefigure, the notion of the saviour-divinity's gradual descent to the world through multiple emanations. ${ }^{58}$ The sun and moon are both themselves divine, and

$5^{6} \quad$ Bermejo-Rubio, 'Further Remarks', 223-24.

57 Ibid. See also Concetta G. Scibona, 'How Monotheistic is Mani's Dualism? Once More on Monotheism and Dualism in Manichaean Gnosis', Numen 48, no. 4 (2001): 455-56.

$5^{8} \quad$ P.Kellis VI, 126. We may already here have a prefiguration of the division of soteriological emanations into separate stages found in the Berlin Kephalaia: in P.Kellis vi Gr. 98, the Mind, King, Christ, has come 1) from the outer aeons, 2) first to the created reality above, 3) then to the created reality below, 4) then to all races in every language. Keph. 7 (1 Ke. 34.13-36.26) lists, in addition to the hidden Father of Greatness, the soteriological emanations as: the Third Ambassador, 'model of the King of Lights' > Jesus the Splendour, 
house divinities responsible for 'wisdom' and 'judgement' (alluding to Jesus the Splendour and the Third Ambassador), to whom souls ascend before entering the 'great aeon'. Soul and life persist in the world through five great lights, i.e. the trapped Light Elements. ${ }^{59}$ In addition to praising the gods, adherents glorify the Elect, who are instrumental in releasing their souls from 'all compulsion and torment and reincarnation'.

Certainly, many divinities known from the Medinet Madi traditions are not specifically named, or occur in variant forms. ${ }^{60}$ It is likely that the terminology was still being shaped when the prayer was written - presumably by Mani himself - as argued by Gardner. While I disagree with the assertion that the religion rapidly turned into 'something that was other than that which Mani professed', ${ }^{\prime 1}$ the notion that technical vocabulary and systematised teachings developed gradually is well-founded.

The practice associated with the prayer seems to have undergone some changes as well. This is indicated by the absence of the verses dedicated to Mani, and the instruction at the end of the Kellis text, which reads: 'blessed is he who prays this prayer frequently, at least three times a day' (1l.124-126). ${ }^{62}$ The number of three daily prayers is indicated by a Parthian Turfan fragments as well, and so al-Nadim's claim that the prayer was said four times a day (by the Auditors) likely reflects a later development. ${ }^{63}$ But even if there were changes in terminology and practice, the key notions of belief were already present in the prayer.

'through whom shall be given life eternal' > the Light Mind, 'father of all the apostles' > the Apostle of Light, who 'shall on occasion come and assume the church of the flesh'. This is consonant with the stages in P.Kellis vi Gr. 98 (omitting the Father of Greatness): 1) the Ambassador located in the sun, i.e. the gate to the 'outer aeons'; 2) Jesus Splendour in the moon, in the heavenly 'created reality above'; 3 ) the Light Mind active in the earthly 'created reality below'; through 4) its manifestation in Apostles of Light, sent to different peoples.

59 Alexander Khosroyev ('Zu einem manichäischen (?) Gebet') argued for identifying these as the five planets, but cf. P.Kellis VI, 113-14; and see Bermejo-Rubio, 'Further Remarks'; Gardner, "With a Pure Heart".

6o E.g. 'the Living God' for 'the Living Spirit' (ibid., 126); 'shining mind, king, Christ' for the Light Mind (and other soteriological divinities, see n.58, above); 'five lights' for the 'five Light Elements'; and 'gods' and 'shining angels' for the divinities entrusted with holding and guarding the world, instead of titles such as 'Sons of the Living Spirit'.

61 Gardner, “With a Pure Heart", 98-99.

62 Initially, Gardner somewhat hesitantly translated this line as 'at least every third day' (P.Kellis VI, 127-28), but this translation is now obsolete. See Gardner, "With a Pure Heart"', 97 .

63 Four is also found in the Uighur communal confession, the Xuastvanift. Gardner, "'With a Pure Heart"', 97. 


\subsubsection{A Prayer to the Light Mind? P.Kellis II Gr. 91}

Finally, we may note a short but complete bipartite prayer contained in a papyrus bifolium, published as P.Kellis II Gr. 91. ${ }^{64}$ The first part (1l.1-18) addresses one or several divinities by a series of titles: 'the firstborn word', 'the father of the intellectual man', 'the mother of life', 'the first apostleship', 'the splendour of the enlighteners', 'our holy spirit', 'the salt of the church' and 'the pilot of goodness'. The second part appeals to be made 'worthy' to be 'your (sg.) faithful' on behalf of 'us', described with another series of epithets ('those who are perfected in you', 'those who are sober in you', etc.). Several of the titles fit the Light Mind: in particular 'the father of the intellectual man' and 'our holy spirit', as Gardner and Worp point out, ${ }^{65}$ but also 'the First Apostleship' (e.g. 1 Ke. 35.2124) and 'the pilot' (e.g. 2 Ps. 161.5-6). The activities of the Light Mind in the bodies of the Elect during the ritual meal could explain the expression 'salt of the church' as well. The piece, then, might be a prayer devoted to this divinity, whose importance is evident also in the documentary letters. The 'Mother of Life', however, is directly identifiable with a different Manichaean divinity. Gardner and Worp suggest that the piece may simply be a piece of popular devotion. ${ }^{66}$ An alternative interpretation that might be broached, however, is that the writer is using juxtapositions ('firstborn' and 'father', 'father' and 'mother') to allude to the idea that different divinities in the end are one and the same, i.e. the active, divine Light.

\subsection{Mani's Epistles}

Like his followers in fourth-century Kellis, Mani was an avid letter writer. His letters became (in)famous in late antiquity, not least because they were collected and promoted as a part of the canonical writings of his Church. ${ }^{67}$ In one chapter of the Berlin Kephalaia, Mani's works are likened to gifts to the community from various divinities. The Living Gospel was from the Third Ambassador, the Treasury from the Pillar of Glory, the Treatise, Mysteries, and Giants all from the Light Twin. Finally, 'all the Epistles that I have written for you from time to time: they are my gifts and my presents'. ${ }^{68}$ This work, then,

64 The editors here, Iain Gardner and Klaas A. Worp, report that Ludwig Koenen has suggested a metrical pattern in the text, potentially implying that this may in fact be a psalm. P.Kellis II, 132 n.417.

65 Ibid., 136.

66 Ibid.

67 For some recent works, see Werner Sundermann, 'A Manichaean Collection of Letters and a List of Mani's Letters in Middle Persian', in New Light on Manichaeism, ed. Jason D. BeDuhn (Leiden: Brill, 20o9); Gardner, 'Some Comments on Mani's Epistles'. 
was intimately associated with Mani himself: less divinely inspired than his other writings, perhaps, and more closely aligned with his work as a preacher and community organiser. Indeed, its content seems to have chiefly related to communal discipline. ${ }^{69} \mathrm{~A}$ copy was still in circulation in the tenth century, as al-Nadim could still list the names of the individual epistles, along with those by other early church leaders, totalling 76 in all. ${ }^{70}$

A large codex of Epistles was found at Medinet Madi, but was subsequently lost. Only a few, mostly unpublished leafs from this codex are in scholarly hands today. ${ }^{71}$ The discovery of fragments stemming from this work at Kellis is therefore of great significance. Pieces of two codices identified as containing letters of a literary nature ('epistles') were published as P.Kellis vi Copt. 53 and 54 in the second volume of Kellis literary texts. ${ }^{72}$ These were found in House 3 , in rooms which also contained documentary letters (Room 6 and 3), but both style and content indicate that they should be assigned to literary works by Mani, in all likelihood his Epistles. Their contents are centred on pastoral matters, such as internal conflicts and discipline, concerns that probably characterise this work more generally. ${ }^{73}$

Gardner further argues that the Epistles evince Mani's authentic Christian voice, in turn suggesting that he primarily saw himself as the 'Apostle of Jesus Christ' and not the Apostle par excellence found in the developed Manichaean Church:

The obvious hypothesis is that the positioning of Mani at the centre and as the fount of the religion is a matter that gradually developed, certainly after his death ... It is only in the scholastic tradition of the Kephalaia and so forth that Mani becomes 'the apostle' in the sense of final or definite revealer in a series, where Jesus becomes only an earlier one. ${ }^{74}$

The use of the Epistles, rather than more 'advanced' Manichaean literature, could be taken to indicate that the community at Kellis saw Mani as a Christian leader whose teachings were primarily ethical and practical, and had limited

69 A gloss contained in the third article of the Chinese Compendium gives one of its eponyms as 'the sacred book of discipline'. Gardner and Lieu, Manichaean Texts, 156.

70 Translated in Reeves, Prolegomena, $115^{-20}$.

71 Together with other preserved material relating to the Epistles, these are being edited by Iain Gardner and Wolf-P. Funk. See Gardner, 'Some Comments on Mani's Epistles', 177 n. 15 .

$72 \quad$ P.Kellis VI, 14-15.

73 Gardner, 'Some Comments on Mani's Epistles', 177.

74 P.Kellis VI, 78; and see Gardner, 'Mani's Religious Development'. 
interest in his cosmology and institutionalised Church. However, as we shall see below, the way these letters frame both their ethical and practical concerns, Mani's own role, and the community as a whole, complicates this picture.

\subsubsection{Discipline and the Soul: P.Kellis vi Copt. 53}

Most of the fragments identified as part of Mani's Epistles belong to a single codex, labelled P.Kellis vi Copt. 53. The codex is not large enough to contain all the letters attributed to Mani; it likely held a selection from the larger corpus. ${ }^{75}$ Eleven leaves from mostly discontinuous parts of the codex have been assigned to it, with material belonging to at least three different letters. Based on the content, Gardner provisionally titled two of these letters the 'Sickness letter' and the 'Enemy letter', respectively, while noting that the Sickness letter has some affinities with a writing known from elsewhere as The Epistle of the Ten Words. ${ }^{76}$

The best-preserved leaves are those assigned to the Sickness letter (leaves 12, $1,6,31-34$, and $51 / 5^{2}$, in Gardner's reconstruction). The author, whose name is lost, styles himself 'apostle of Jesus Chrestos'. He addresses a man whose name is also lost and the brethren who are with him (P.Kellis vi Copt. 53,12.1-6). He invokes 'the Father, the God of Truth' and asserts that he has sealed his interlocutors in himself (12.13-14), giving emphasis to his authority. These features make an identification with Mani all but certain. In the first preserved bulk of the letter-body (leaves 31-34) he describes a dire sickness he is suffering from, which has been exacerbated by a letter sent by the addressee. In the mostly illegible mid-section of leaf 31, the words 'congregation of the holy ones' (31.12) and 'envy and quarrelling' (31.16) can be read: conflict within the congregation appears to be the topic. In the next leaf, it becomes clear that the addressee, in a previous letter, has complained about an adherent who has uttered (evil) words against another member of the community (32.1-5). Mani now responds, saying that by wounding one person, the offender has unwittingly wounded 'the entire righteousness and godliness' (32.8). The addressee should speak gently with the offender to lead him away from such sin. The next two leaves (33-34) are more fragmented, but continue the topic of problems within the church, as a passage reads: 'For there are people of this kind in church, who are not strong; rather they look for excuses and empty words' (33.23-25). In the last page assigned to this letter, leaf 51 , Mani seeks to encourage the (now plural) addressees by stressing the need for living up to their ideals. The passage contains a strong formulation of his own role within the community:

75 P.Kellis II, 13. See also Gardner, 'Once More on Mani's Epistles', 294-95.

${ }_{76}$ For the details of the reconstruction of these letters, see P.Kellis VII, 11-27. 
Remember your first faith that you had in your youth: How I laboured in the congregations of the sects ( $\overline{\mathrm{N}} \mathrm{C}$ Y $2 \overline{\mathrm{C}} \overline{\mathrm{N}} \mathrm{N} \triangle \mathrm{O}$ OrMd) when there was yet no catechumens and no church. You have become people made better by blessed poverty. Now, since you have been bringing forth catechumens and churches - you proclaimed and they listened to you - you are obliged the more now to perfect the blessings of this poverty, by which you will gain the victory over the sects and the world. It is profitable for you to perfect it and be vigilant in it; because poverty is your glory, the crown of your victory.

P.Kellis vi Copt. 53,51.1-17

The author, then, is clearly Mani, while the addressees must be leading Elect ('bringing forth catechumens and churches') who have turned to him for a ruling on a breach of discipline among themselves. In answer, Mani invokes his role as founder: at the time he began his mission there were no catechumens or church, and he had to toil among the 'sects'. These Elect should cherish their good fortune, as Mani has prepared the way for their victory. He here makes a powerful statement concerning his own authority, often repeated by later ecclesiastical sources: Mani had not relied on a pre-existing community, but made his own 'good election' in opposition to the 'sects' (e.g. 1 Ke. 16.3), creating a superior Church where true practice of blessed poverty could proliferate (e.g. 1 Ke. 13.30-14.7). ${ }^{77}$

A similar passage on troubles within the community comes from another letter in the same codex, the Enemy letter. Here Mani relates how some people have come to him slandering the addressee, apparently a senior member, in order to make Mani remove him:

$[\ldots]$ who are in the church [...] who came to the [... they (?)] sent and $[\ldots]$ to me $[. .$.$] you, they wishing to defile [you ...] This should never hap-$ pen. They are thinking: "If we are able to report all these words before

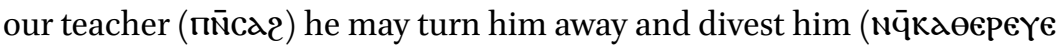

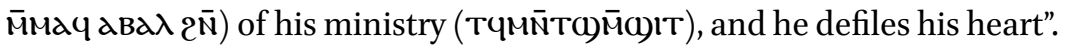
However, I, this is what I have done: The people who proclaimed these words before me, wishing to defile you; I have gone to them with strong words according to their worth.

P.Kellis vi Copt. $53,61.7-20$ 
Mani sees through them, and instead it is the accusers who are rebuked. This passage shows that the community Mani is speaking of, as hinted at above, already had its own institutions, with officials organised in a hierarchy. 'Teacher' (ca2), the title applied indirectly to Mani, is clearly not solely a master of students: it is an office with the power to divest ( $\kappa \propto \theta \alpha i p \varepsilon \dot{\varepsilon} \omega$, 'put

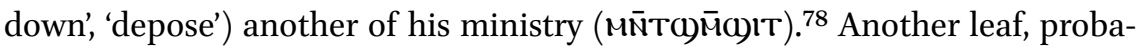
bly belonging to a third letter, concerns the errors of a certain presbyter. It gives a similar impression, and reads:

And any presbyter whom you $(s g).[\ldots]$ on one or two occasions, and he does not [...] and he does not take from you my teaching: Write to me and tell me who or where he is, so that I myself will know him; this person who is inferior in this manner, who hates his benefit. For understand that there is no more severe sin for this presbyter, before me, than this one: That he does not receive this teaching that I have proclaimed for him. Now, when someone will [not] receive [...] you are obliged to send [me (a message) and ...] him so that I will know.

P.Kellis vi Copt. $53,81.2-15$

Mani demands that the presbyter's wrongdoings be reported to him. ${ }^{79}$ As in the passages from the Sickness letter and the Enemy letter, breeches of discipline and conflicts between Elect are to be handled within the structure of the community. The principle of mutual observation of Elect by Auditors has recently been stressed by BeDuhn, as a control mechanism that increased pressure on the Elect to act in accordance with the discipline. ${ }^{80}$ This letter strengthens the impression that mutual observation played a central role. Mani, as a superior, was to be informed and take action against trouble-makers. A system of observation and report was to regulate behaviour among adherents. Considering that the addressee is an Elect, and likely a senior member, such supervision was not considered as limited to Elect-Auditor relationships, but was to pervade the entire Church. As we shall see in Chapter 9, peer scrutiny between Elect was a central tool in the Manichaean institutional repertoire also in practice.

78 Perhaps the title of teacher being ascribed to Mani by himself here explains why the archegos, the head of the Church and Mani's 'heir', on Augustine's testimony in De haer. (46.16) was considered first among the other teachers, and not a (completely) separate office.

79 It is interesting to see this passage in connection with an unfortunately very fragmented chapter from the Berlin Kephalaia; keph. 166. As in the letter from Kellis, a rogue presbyter and the sending of messages are central features of this kephalaion (1 Ke. 411.15, 412.1-3).

BeDuhn, 'Domestic Setting', 264-65. 
The above suggests that disciplinary concerns were of primary interest in the letters. Nonetheless, there are points at which cosmological notions intrude. In the Enemy letter, Mani alludes to the body's 'bondage', telling his followers:

The word that our lord proclaimed with his mouth has been fulfilled with me ... All these things I have endured from my children and my disciples; they whom I saved from the bondage of the world and the bondage of the body. I took them from the death of the world. I, all these things I have borne and endured from time to time, from many people.

P.Kellis vi Copt. $53,41.15^{-20}$

He continues by exhorting the Elect addressees to prepare for 'long-suffering', and be like an athlete, a 'good priest', and a farmer who tends a vineyard, and takes its fruits to his master $(42.22-25)$. This latter metaphor may well allude to the role of the Elect in refining Light and sending it to the Father: especially as the discussion on the next leaf also concerns 'our exalted soul' (TNYYYXH ETXACE), which Satan has lied about, and which is the light of the Father 'which enlightens the world' (43.16-17), i.e. the trapped Light Soul. Mani exhorts: 'Again, pay heed to your $(p l$.$) exalted soul, that is, the life of the uni-$ verse which is spread out in every place; for how many are the wounds, how great the terrors endured by (?) humanity' (43.19-24). ${ }^{81}$ This is an explicit reference to the world soul, in which the addressees also take part, and which can be wounded by sin. Again, in the Sickness letter, one offender, by an act of transgression, had sinned against 'the entire righteousness and godliness' (32.8): a cosmic wrong caused by an unwitting human agent. Here we find Mani making connections between macrocosmic forces and individual ethics, similar to the (admittedly more abstract) mythological-ethical reasoning concerning divinities and virtues from the 'scholastic' traditions, in e.g. keph. 38 and P.Kellis vi Gr. 97.

\subsubsection{Communal Love: P.Kellis vi Copt. 54}

A leaf assigned to a different codex, P.Kellis vi Copt. 54, also contains a text that can be attributed to Mani, although its classification as one of his Epistles is less clear. ${ }^{82}$ The first legible part concerns an unknown logion by a 'saviour' on love and redemption. Again, Mani asserts his own position: 'I, I [give] strength to my [limbs (?); these] whom I gather in' (ll.7-8). This echoes the Berlin

81 See also P.Kellis vi Gr. 98 (ll.73-75), and the discussion above.

82 See P.Kellis VI, 85, 91. Gardner has more recently suggested that it might be plausibly identified with the 'Letter of the Seal', where Mani sealed the community in his love. Gardner, 'Once More on Mani's Epistles', 310-14. 
Kephalaia, where Mani is often made to refer to his adherents as 'limbs', ${ }^{83}$ and furthermore stresses that it is by his authority that adherents are 'gathered in', i.e. redeemed. Next, Mani stresses the completeness of the revelations that he has offered, through the citation that opened this chapter:

You do not lack anything from [the] mysteries of the wisdom of God. Much is [... the] wisdom that I have proclaimed to [...], that which I have written [for] you in [my holy books?]. You do [not lack] anything from the wisdom. There is only this one thing: devote yourself to what is written. (ll.12-17)

He then prays that they the recipients possess love for each other and avoid 'divisions, disharmony, quarrels or reproaches' (ll.2O-21). He exhorts them to practice 'love and gentleness' (ll.23-24). Towards the end of the leaf, he comes with an injunction concerning love between the different grades of the community, which in Gardner's translation reads:

you will love one [another]: the [teachers] will love the teachers (īcd2),

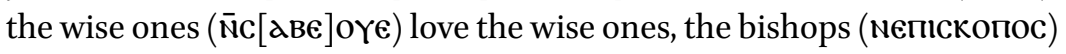

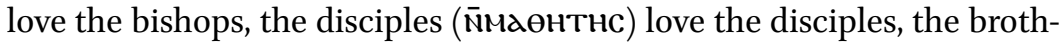
ers love the brothers, also the sisters love the sisters; and you will all become children of [a] single undivided body (coma). Now, [this is] the way that you should behave, my loved ones, so that you will all possess this one love [and one (?) ...]; because this love is the seal [of] all your deeds. For these bodies [belong to] you for a little while. Therefore, man [cannot remain] without the seal [of] the love [of his] brotherhood and that of his redeemer. (1l.49-63)

Mani here proclaims that the disposition of love is to govern internal relationships between members of the community, in order to create a 'single undivided body'. As in the cases of errant Elect above, the focus is on unity and harmony within church ranks. ${ }^{84}$ The title of 'teacher' heads the list, demonstrating that it had already received prominence within the Church, as is also shown by its application to Mani in the Enemy letter above. The other titles are not in accordance with later lists, however. The office of 'bishop' is listed third, replacing the office of 'presbyter' - although this office is found in the

83 As adduced in Chapter 5 , Section 5, n.87.

84 A similar emphasis of intra-communal 'love' is also found in 1 Ke. (e.g. keph. 63, 'Concerning love'). 
above-cited P.Kellis vi Copt. 53. It may suggest that the precise order and terms were not as fixed at the time of the writing of these letters as they became at a later stage..$^{85}$ The relationship between, and/or translation of, these terms may have undergone development. Nevertheless, the importance of a hierarchical structure at an early date is clear.

From the above examination, it emerges that while the Epistle fragments from Kellis certainly focus on matters of ethical conduct and discipline, they frame these issues within the boundaries of an institutionalised, socio-religious body. The originator and final authority of this body is Mani, and it seems to me that his role as the final 'apostle', whose revelations legitimised a new movement, are already present here. It is seen in his claim to have founded a completely new Church in the Sickness letter, his self-presentation as having 'saved' the addressees and fulfilled the words of Jesus in the Enemy letter, and especially the emphasis on his own revelations as providing the complete truth in P.Kellis vi Copt. 54. Citations from his other writings, such as the Living Gospel and $\breve{S}$ abuhragan, point in this direction as well. ${ }^{86}$ Not least, the practical matters he attends to are anchored in his cosmological system. Mani's Epistles may primarily have dealt with ethical and disciplinary issues - although letters known from others sources are known to have featured detailed myth - but the ethics expounded there were not easily separated from cosmological notions. ${ }^{87}$

\subsection{A Proto-Kephalaion?}

We have already seen that the notions discussed at the beginning of this chapter are present in the Kellis literary papyri. Close engagement even with more esoteric, cosmological details is evinced by a wooden board discovered in House 3 , T.Kellis II Copt. 1, which may moreover suggest a didactical purpose. The board contains a Coptic text listing the five properties (cXHMd) of the divinity known as the Third Ambassador, who 'exists corresponding to five properties of the Father' (1.3). He is described as 1) exalted, 2) king, 3) a light dispersed over aeons, 4 ) hidden, and 5 ) in possession of Twelve Virgins. ${ }^{88}$ For each, except in

$85 \quad$ See P.Kellis VI, 92 n.31.

86 Reeves, Prolegomena, 97, 102-3.

87 That other letters concerned themselves with 'myth' is evident. Mani's Fundamental Epistle, read to Augustine as an Auditor and attacked by him early in his episcopacy, 'in which almost the whole of what you believe is contained' (c. ep. Man. 5 , trans. Teske, The Manichaean Debate, 236), was centrally concerned with the war between Light and Darkness, and described the aspects of the respective realms in detail.

88 The Twelve Virgins were a set of divinities that manifested the effects of the disciplinary regime on the Elect body, according to texts found at Turfan. Whether this concept was fully systematised in the western tradition is unclear. BeDuhn, The Manichaean Body, 226. See also 1 Ke. 97.7-19. 
the case of the third, it is emphasised that the Third Ambassador's properties are modelled on those of the (highest) 'Father' with his Aeons, i.e. the Father of Lights, God of Truth. The third property, that of being 'dispersed' in all the Light, explicitlyreflects the notion of higherandloweremanations ultimatelybeing the same deity.

The catechetical style of listing, and the division of processes and divinities into categories of five, are important characteristics of the Berlin Kephalaia. On the other hand, it lacks the literary frame that attributes the information to 'the Enlightener' or 'the Apostle', also characteristic of that work. ${ }^{89}$ Pettipiece has seen the prevalence of lists of five as part of a process of systematisation which he calls 'pentadisation' conducted within the scholastic tradition of the Church. ${ }^{90}$ Whether the board represents an urtext of kephalaic material, later incorporated in such a systematisation, or was itself derived from an authoritative collection such as the Berlin Kephalaia, is not known. Gardner, followed by Pettipiece, appears to prefer the former solution. ${ }^{91}$ However, the process by which such urtexts were created and canonised, if they did not already derive from authoritative attempts at systematisation, seems to me to require more attention if this hypothesis is to be accepted. At any rate, this text clearly shows that 'scholastic' modes of discourse were current in Kellis. But who was if for? The board would appear to have been a teaching or mnemonic instrument, given its rough production and schematic list of aspects without a literary framing. Gardner describes it as 'a "flip card", utilised for the easy learning of the complex details of Manichaean doctrine', and goes on to write:

The personal letters from Kellis evidence that the lay faithful regarded Manichaeism as a kind of superior Christianity; and the specifically Manichaean divinities such as the Third Ambassador rarely intrude. It would seem that in their evangelical mission the elect presented the faith as that of the true church, and as the fulfilment of Jesus' teaching. Catechumens would then be slowly drawn into the community and gradually introduced to the higher knowledge of Mani's revelations. This process is also apparent from Augustine's writings.... It also suggests the presence of elect at Kellis. ${ }^{92}$

89 See P.Kellis II, 4-7.

90 Timothy Pettipiece, Pentadic Redaction in the Manichaean Kephalaia (Leiden: Brill, 2009).

$91 \quad$ P.Kellis II, 4; Pettipiece, Pentadic Redaction, 12.

$92 \quad$ P.Kellis II, 4. 
The distinction between presenting the faith as the 'true church' of Jesus and slowly drawing believers into the higher mysteries is not clear to me the Elect would presumably have seen no distinction, just a gradually more complete and more satisfying account of the faith made manifest by Jesus, explained and revealed by Mani. The Third Ambassador figured, as we saw, in the prayer in T.Kellis II Copt. 2A5. He was not a secret divinity reserved for the few, even if he was not often invoked, and his specific attributes were probably primarily known to those who made further studies. The presence of this board raises intriguing questions regarding the interaction between Elect and laity in House 1-3. It was found in the same room and deposit level as material written by Auditors. ${ }^{93}$ It may have been used by an Elect lecturing or instructing Auditors on the role of the Third Ambassador, and then for some reason been left behind. But it could also be that the board was copied by an Auditor, perhaps from a text provided by an Elect. At any rate, the mundane context in which it was found must be taken to indicate that this board was intended for use among the laity. ${ }^{94}$ It shows that the appropriation of 'esoteric' knowledge was not restricted to the circles of Elect, but was explained to and even memorised by some lay believers.

\section{3} Textual Practices

The above examination shows that all the key notions of the Manichaean world were present in the literary texts found at Kellis. It furthermore suggests that texts played a vital role for the laity there. But in what way? And how did they impact shared identity? In order to elucidate these questions, we may draw on Brian Stock's concept of textual community. ${ }^{95}$ This concept was developed in

93 Room 11 (dep. 4), containing letters by Pekysis to 'father' Horos I (P.Kellis viI Copt. 78-79); P.Kellis I Gr. 81 by Sabinos to Elias dealing with a landlord; and P.Kellis viI Copt. 93, by Timotheos to Talou, concerning freight.

94 Another find of a similar character is the unfortunately very fragmented text in P.Kellis II Copt. 8, from House 2, which may also contain kephalaic material. It features an exposé on day and night, and the heights (and the depths), corresponding to similar teachings of Mani. P.Kellis II, 96-97.

95 For this notion applied to ancient Christianity, see Robin Lane Fox, 'Literacy and Power in Early Christianity', in Literacy and Power in the Ancient World, ed. Alan K. Bowman and Greg Woolf (Cambridge: Cambridge University Press, 1994); Lieu, Christian Identity, 28-36; Bremmer, 'Social and Religious Capital'; David Brakke, 'Scriptural Practices in Early Christianity', in Invention, Rewriting, Usurpation:Discursive Fights over Religious Traditions in Antiquity, ed. Jürg Ulrich, Anders-Christian Jacobsen, and David Brakke (Frankfurt: Peter Lang, 2012). For a critical discussion, see Jane Heath, “Textual Communities”: Brian 
order to grasp the relationship between text and social formation, designating 'a community whose life, thought, sense of identity and relations with outsiders are organised around an authoritative text. ${ }^{96}$ It emphasises that only one or a few members need to have a literate education in order for texts to play a central role in producing a shared identity, the others being socialised into the community through participation in practices structured by texts. It alerts us to the need for examining the specific ways that texts were embedded in practice. The concept was originally applied to the interplay between 'heretical' groups and their usage of Biblical texts in the Medieval era. For social formations in antiquity, it has been operationalised in a variety of ways. ${ }^{97}$ Here we note its application to Christian communities in late antique Egypt by David Brakke. He has sought to make it explicit by focusing on the institutions that shape the usage of religious texts, which he terms 'scriptural practices'. ${ }^{8}$ Provisionally, he identified three scriptural practices in the Christian Church: study and contemplation, continued inspiration, and communal worship. In the following, we look at the first and last of these categories in relation to the Kellis material.

\subsection{Individual Practices: Studying and Copying}

Let us start by identifying those instances where texts are mentioned in the documentary evidence. There are in fact ample references to 'books' (хФмє). Many of them are from the Maria/Makarios circle, but far from all. ${ }^{99}$ Certainly, it is not always made explicit that religious texts are meant. But in the case of all three letters where book titles are mentioned, religious texts are meant: Makarios names a substantial number of such texts in P.Kellis v Copt. 19, including Psalms, The Epistles, and The Judgement of Peter, while both P.Kellis $\mathrm{V}$ Copt. 33 (ll.3-4) and P.Kellis vir Copt. 120 (ll.2-7) mention 'the Gospel', and the latter also 'the Acts' (see Table 6, below). None of the texts state that the works are of specifically Manichaean provenance. The Gospel, Acts, Epistles, Psalms, and so forth could, perhaps, be mainstream Christian texts. This seems most likely in the case of the Apostolos, a common term used to designate Paul's letters. ${ }^{100}$ Still, in the case of psalms, prayers, and Epistles, we have, as seen above, many examples of specifically Manichaean texts found in situ. It seems

Stocks Concept and Recent Scholarship on Antiquity', in Scriptural Interpretation at the Interface between Education and Religion, ed. Florian Wilk (Leiden: Brill, 2018).

96 Heath, “'Textual Communities"', 5 .

97 Ibid., 14-29.

98 David Brakke, 'Scriptural Practices', 268.

99 For Maria/Makarios, P.Kellis v Copt. 19-21, 24, 26; for others, P.Kellis v Copt. 33-35, P.Kellis viI Copt. 111, 120, P.Kellis I Gr. 67.

100 P.Kellis VII, 294; and see Brand, 'Manichaeans of Kellis', 298-99. 
TABLE 6 Religious books in the documentary papyri

\begin{tabular}{|c|c|c|c|}
\hline Title & Text & Coptic spelling & Circle \\
\hline $\begin{array}{l}\text { Epistles, large/ } \\
\text { small }\end{array}$ & $\begin{array}{l}\text { P.Kellis v Copt. } 19 \\
(11.82-83)\end{array}$ & 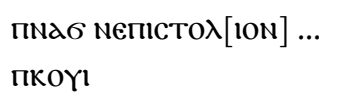 & Maria/Makarios \\
\hline Judgement of & P.Kellis v Copt. 19 (l.15) & 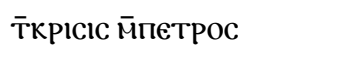 & Maria/Makarios \\
\hline Peter & P.Kellis v Copt. 19 (1.84) & 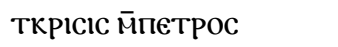 & \\
\hline Greek Psalms & P.Kellis v Copt. 19 (l.16) & $\bar{N} Y a[\lambda] \operatorname{MOC} N[O Y l d N] \mathbb{N}$ & Maria/Makarios \\
\hline Apostolos $^{\mathrm{a}}$ & $\begin{array}{l}\text { P.Kellis v Copt. } 19 \\
\left(11.15^{-16)}\right.\end{array}$ & {$[$ пап]остолос } & Maria/Makarios \\
\hline Great Prayers & P.Kellis v Copt. 19 (l.16) & $\bar{N} N \lambda G \bar{N}() \lambda H \lambda$ & Maria/Makarios \\
\hline Prayer-Book & P.Kellis v Copt. 19 (1.84) & $\pi € \gamma \times \omega N$ & Maria/Makarios \\
\hline Sayings & P.Kellis v Copt. 19 (l.17) & N̄PHMd & Maria/Makarios \\
\hline Prostrations & P.Kellis v Copt. 19 (l.17) & $\bar{N} K \lambda ı \mathrm{ICIC}$ & Maria/Makarios \\
\hline \multirow[t]{2}{*}{ Gospel } & P.Kellis v Copt. 33 (l.4) & {$[\pi є ү \lambda] г г е \lambda ı N$} & (Theognostos?) \\
\hline & $\begin{array}{l}\text { P.Kellis viI Copt. } 120 \\
\left(11.5^{-6}\right)\end{array}$ & пеүаггеגION & Pamour/Pekysis \\
\hline Acts & $\begin{array}{l}\text { P.Kellis VII Copt. } 120 \\
(11.3-4)\end{array}$ & Niחраzєıс & Pamour/Pekysis \\
\hline
\end{tabular}

a The title 'Apostolos' also occurs in P.Kellis viI Copt. 127, a letter written in Sahidic from Area D. The editors there suggest that it refers to a collection of Paul's epistles. P.Kellis VII, 294.

reasonable to suggest that the Gospel that circulated in the lay network at Kellis similarly was Mani's Living Gospel, which is indeed mentioned in the psalm of T.Kellis II Copt. 7. It contained material pertaining to Mani's life as well as descriptions of distinctive Manichaean mythological and doctrinal themes. ${ }^{101}$ While it may well have been a comparatively rare book, it does not in any way seem to have been kept secret or restricted.

Turning to the practices associated with these texts, it is perhaps no surprise that reading is among them. Two letters mention 'reading' of books, both explicitly religious: in an unfortunately fragmented passage from P.Kellis $\mathrm{v}$ Copt. 33, the unknown author (perhaps Theognostos) writes: '[Write to (?)]

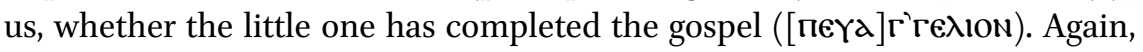

101 Wurst, 'Létat de la recherche', 249; Funk, 'Mani’s Account'. 
if $[\ldots]$ then do $[\ldots]$ cover $[\ldots]$ quickly; in that he $[\ldots]$ read the epaggeliai

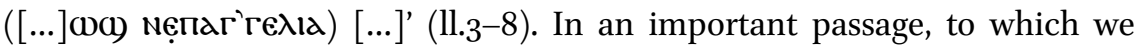
return several times below, Makarios admonishes Matthaios to read a range of texts:

Study [your] psalms, whether Greek or Coptic <every> day (?) [...] Do not abandon your vow. Here, the Judgment of Peter is with you. [Do the] Apostolos; or else master the Great Prayers and the Greek Psalms. Here too, the Sayings are with you: study them! Here are the Prostrations. Write a little from time to time, more and more. Write a daily example, for I need you to write books here.

P.Kellis v Copt. 19, ll.13-19

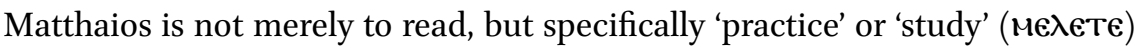
his texts. The role of study and contemplation has already been explored for Manichaeism by Jason D. BeDuhn, who used evidence from Kellis to argue for the centrality of books to Manichaean identity. He emphasises that texts played a central role in shaping individual identities among literate Manichaeans, their importance for the 'private, individualized spiritual development, for the permanent access of the individual to religious instruction even in the absence of religious authorities and professionals. ${ }^{102}$ In addition to study, Makarios admonishes Matthaios to 'write a daily example' in P.Kellis v Copt. 19. This attests to another practice: the copying of texts by local adherents. There are many mentions of writing or copying in the letters. ${ }^{103}$ For most of these, too, a religious context is clear. In the above-quoted passage from P.Kellis $\mathrm{V}$ Copt. 33, the author wrote that the Gospel had been finished by a 'little one'. In P.Kellis viI Copt. 120, addressed to Pamour (III), the author writes: 'About this book that Lamon has: Let the Acts be copied. But the Gospel: Let them bring it to me from father Pabo' (ll.3-7). Pamour is to have the Acts copied, either by himself or by someone else. That members of the Pamour family themselves were involved in copying literature is attested to by two letters to Psais III, P.Kellis v Copt. 35 and P.Kellis VII Copt. 111. They concern the copying of 'tetrads', and Psais III actively participates in copying texts himself. In the former letter, Ouales writes:

\footnotetext{
102 BeDuhn, 'Domestic Setting', 269.

103 P.Kellis v Copt. 19, 24, 33, 35; P.Kellis vir Copt. 111, 120; and perhaps P.Kellis I Gr. 67 (see below).
} 
I beg you, my lord brother: if you can write these tetrads for me, which I sent to you, I will cause what is written to be brought to you too; so that you can know where they have reached. Look out (?) whether he has not been negligent writing them. Quickly, you send them to me by a blessed one; for they say: "We want someone else to write the other ones". Now, do not neglect to send them quickly. By no means! I did it for the great texts; (but it is) because they say that the papyrus has run out. Still, writing is what is useful; and if you do write them, I for my part will find your recompense. I am no fool!

P.Kellis v Copt. $35,11.36-46$

On this text's first publication, the editors suggested that the 'tetrads' may be understood as papyrus quires consisting of four double leaves, i.e. quaternions. ${ }^{104}$ If so, the copying of 'tetrads' involves the copying of text onto clean papyri. Given the presence of a 'blessed one', and the oath sworn by the Paraclete some lines earlier, it is highly likely that the texts to be copied - the

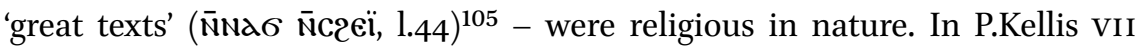
Copt. 111, 'brother' Pebos likewise admonishes Psais III to keep writing 'tetrads', even though he has already written a great many. Perhaps we might add P.Kellis I Gr. 67, in which Lysimachos writes: 'Send a well-proportioned and nicely executed ten-page notebook for your brother Ision. For he has become a

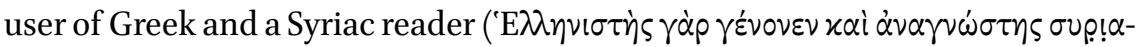
$\tau \tau \tau x o ́ \varsigma) '(11.17-21) .{ }^{106}$ The aside regarding Ision's reading ability implies that the 'notebook' or 'tablet' ( $\pi$ ivaxíitov) was to contain a text of some kind, and so the recipient, Theognostos, was presumably to copy one onto it (perhaps even in Syriac). ${ }^{107}$ The cases of Matthaios, this 'little one', and Psais III suggest that it was common practice to have young men acquire literary skills by copying books as part of their religious practice. It seems to be echoed by the materiality of the texts: the number of different and coarse hands visible in the psalms prompted Gardner to suggest that copying scripture was deemed a spiritual task, practised by 'the whole believing community'.108

104 For this suggestion, and the text itself, see Paul Mirecki, Iain Gardner, and Anthony Alcock, 'Magical Spell, Manichaean Letter', in Emerging from Darkness, ed. Paul Mirecki and BeDuhn (Leiden: Brill, 1997), 31.

105 Note the alternate translations suggested by Brand 'Manichaeans of Kellis', 296.

106 For this translation, Iain Gardner, 'P. Kellis I 67 Revisited', Zeitschrift für Papyrologie und Epigraphik 159 (2007).

107 The address was written in Syriac, and so Theognostos was presumably conversant with this language. Syriac texts and translation tools were, as previously noted, found in Kellis.

108 P.Kellis VI, 6. See also Iricinschi, 'Tam pretiosi codices', 157-59. 
This brings us to another practice, namely the intertextual use of Manichaean literature - the employment of Manichaean cues. By studying and copying religious books, literate members would have internalised typical Manichaean literary allusions and rhetorical devices, as we may well have seen some examples of in Chapter 5. It is explicitly on display in Makarios' P.Kellis v Copt. 19, where he uses a citation of the 'Paraclete' in order to reinforce his message to Matthaios: 'Now, be in worthy matters; just as the Paraclete has said: "The disciple of righteousness is found with the fear of his teacher upon him even while he is far from him, like (a?) guardian"' (ll.8-11). ${ }^{109}$ It is quite possible that such cues may have been derived from textual transmission. However, considering that the usage of cues extended to members who probably had a lower level of literacy than Makarios, such as Pamour III and Tekysis III, we should consider other routes as well. In particular, we may look to communal practices - which also had important textual dimensions, as we shall see.

\subsection{Communal Worship: Almsgiving and Ritual Performance}

While studying and copying books may have had important individual dimensions, books were not only for one's own, private contemplation. For one, there is evidence that books were communally held. Books certainly circulated widely among, and were widely available to, the laity. Makarios bade Maria I obtain the Great Epistles from 'mother' Kyria I, by way of 'daughter' Drousiane in P.Kellis v Copt. 19 (1l.73-74, 82-84), and the family's literary network included figures such as Ouales, Pebo, and Pekos. Books were sent across long distances; requests are found for books to be sent from Kellis both to the Nile Valley (P.Kellis v Copt. 19, 20) and Hibis (P.Kellis viI Copt. 111). Makarios' aside to Matthaios in P.Kellis v Copt. 19, that he had a 'need' for Matthaios 'to write books here', indicates that there was demand from a wide circle of readers.

An explanation for this demand may well be that the religious aspect of book-copying by young members, discussed above, constituted a form of almsgiving to the Holy Church. This is known to have been part of the religious obligations of lay Manichaeans in Turfan, where copying books on behalf of the 'religion' is indeed described as almsgiving. ${ }^{110}$ It is supported by the contexts in which the requests for Psais III's writings occur. The figure of 'father' Pebo/Pabo in P.Kellis viI Copt. 111 may be identifiable as an Elect presbyter, as

109 For this reconstruction, see Gardner, 'A Letter from the Teacher', 321 n.7. For another citation, see perhaps the letter of Ammon, as noted in P.Kellis $V$, 233-34.

110 See the discussion in Section 4, n.117, below, and Andrea Piras, "The Writing Hearer: A Suggested Restoration of M 1o1d', in Zur lichten Heimat. Studien zu Manichäismus, Iranistik und Zentralasienkunde im Gedenken an Werner Sundermann (Wiesbaden: Harrasowitz, 2017). 
argued in Chapter 9. Ouales, in P.Kellis v Copt. 35, relates that a plural 'they' are responsible for ordering the writings, indicating the existence of superiors. ${ }^{111}$ Another passage alludes to a 'brother' Kallikles, who seems to be some kind of authority, while a 'blessed one' is requested in order to bring the texts from Psais III to Ouales. That several Manichaean authorities were interested in the production and collection of such writings strongly indicates that we should take Psais III's tetrads as alms.

At any rate, the texts themselves where not only used for individual reading. While studying would have been of great significance for some, it was not something every member of the community could engage in. We should certainly not imagine that the community at Kellis was made up only of literate people. For these texts to play a role beyond the immediate users, then, they would have to be embedded in communal textual practices, such as communal readings. BeDuhn, whose emphasis was, as we saw, on the individual aspect of textual usage, noted that 'all of the references to reading or copying texts in the Kellis documents seem to assume private study'.12 However, there is in fact one clear reference to communal readings: Matthaios describes how his brother (i.e. Piene) has been honoured by the Teacher, who 'loves him very much, and

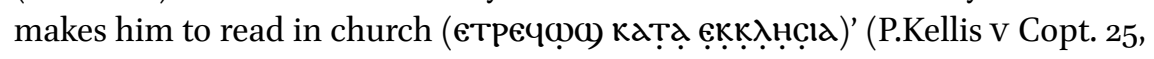
1l.45-46). This presumably relates to the public reading of religious text in a liturgical context. Such occasions are mentioned by Augustine, who relates that he attended worship where Mani's writings, such as the Fundamental Epistle, were read. ${ }^{113}$ The remains of Mani's Epistles found at Kellis may well have been used in such settings. Admittedly, Matthaios refers to practice among Manichaeans in Alexandria, where Piene was located. However, it does not seem unlikely that similar readings occurred in Kellis - certainly, the recipients of Matthaios' letter must have been aware that it was common practice. It may be argued that an absence of local Elect in Kellis made formal church readings uncommon there, on the assumptions that Elect presence was necessary for such meetings to take place, and if the argument recently advanced by Mattias Brand, that the Elect were generally absent from Kellis, is correct. However, as I argue in the next chapter, there is much evidence to suggest that Elect visited Kellis, even on a regular basis. ${ }^{114}$ Nor should we exclude

\footnotetext{
111 As also pointed out by Mirecki, Gardner, and Alcock, 'Magical Spell', 3 o.

112 BeDuhn, 'Domestic Setting', 269.

113 C. epist. Man. 5. See Johannes van Oort, 'The Young Augustine's Knowledge of Manichaeism: An Analysis of the "Confessiones" and Some Other Relevant Texts', Vigiliae Christianae 62, no. 5 (2008): 454.

114 For Brand's argument and my own views, see Chapter 8, Sections 1 and 3.1.
} 
the possibility that literate laity took it upon themselves to arrange such meetings: the textual finds certainly show that they had the tools to do so.

The mention of Psalms in Makarios' letter P.Kellis v Copt. 19 points indirectly to another communal practice in which texts played a role, namely that of psalm singing. This is indicated by the material remains surveyed above. As we have seen, the abbreviated psalms of T.Kellis II Copt. 2 indicate that the codex-boards were used as memory-aides for singers; presumably to be sung at church gatherings. One of the psalms examined above, T.Kellis II Copt. 4a, corresponded to the Bema Psalm 222: it may that it was intended to be sung at the local celebration of the Bema-festival, when Mani's suffering and death was commemorated. The religious cues considered previously, moreover, find many echoes in the Manichaean psalms. So, for instance, the image of 'fruits of the flourishing tree' in the opening of Makarios' P.Kellis v Copt. 22 is found in Psalm 249 and in Psalm 261, the latter of which has been identified at Kellis (T.Kellis II Copt. 6). Other Manichaean epistolary cues also echo psalms found at the site: the phrase 'children of the living race', from the same letter, occurs in T.Kellis II Copt. 4b, and the phrase 'elect and catechumen', used in the closings of Horion's letters (P.Kellis v Copt. 15-17), is found in the doxology of the psalm P.Kellis II Copt. 2C1 (ll.70-71).

Books clearly had a function in communal practice at Kellis. It may be even that be that they were placed on special cushions in order to be displayed on ritual occasions: in P.Kellis v Copt. 21, Makarios asks Maria I to send 'the dyed

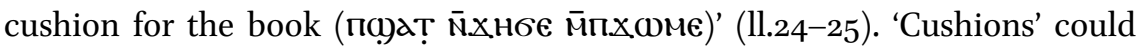
have provided ceremonial resting places or decorative trappings for certain books, presumably to give them a special aura when taken out and displayed in communal settings, although this interpretation requires more substantiation. ${ }^{115}$ Most of the literary texts from Kellis were clearly not of the sort that were only put on display.

Religious literature at Kellis, then, was studied, cited, copied, read, sung, and circulated widely in the community. Clearly, textual practices had a relatively central place in lay religious life. But what role did such practices play in shaping a Manichaean identity? Given that the literary texts used by the

115 P.Kellis V, 174; Brand, 'Manichaeans of Kellis', 153-54. For Manichaean use of imagery from Mani's Picture-Book in congregational settings, see Gulácsi, Mani’s Pictures. 
Auditors did not shy away from central and particular Manichaean doctrines, we may well imagine that they functioned to introduce them to such ideas, and allowed the Auditors to appropriate them as part of their Manichaean identity. However, it might be argued that mere references to myths and beliefs in liturgical settings would not necessarily have functioned to impart knowledge of them to a wider audience, far less internalise 'beliefs'. BeDuhn, in his work on the ritual meal, cites a study of ritual language indicating that such utterances do not function primarily as communicative acts for disseminating stories or teachings. ${ }^{116}$ Nor does ritual depend upon members understanding the 'underlying' doctrines. Manichaean authorities may not even have intended them to have such a function: allusions to the 'mysteries' could have been aimed at the Elect, who would know their true significance, congruent with the depiction of Elect as guardians of a 'Manichaean world'.17

Yet, there are to my mind good reasons to think that it often functioned to facilitate lay appropriation of distinct Manichaean ideas. For one, Manichaean authorities did make a concerted and conscious effort to promote knowledge of their cosmology through the liturgy. Gardner has noted the frequency with which lists of emanations occur in Manichaean psalms, indicating

116 BeDuhn, The Manichaean Body, 241.

117 It has similarly been suggested that Auditors were barred from reading or handling Mani's books. Claudia Leurini, for instance, has argued that Mani's script was reserved for religious books in order to make them inaccessible. As evidence she refers to Augustine, who according to Kevin Coyle gained deep knowledge of Manichaeism only after having confiscated books as a Christian bishop. She also cites a line from a series of parables found in a codex containing the Book of Giants at Turfan: 'the Hearer that copies a book, is like unto a sick man .... In her view, it implies that Auditors were forbidden to 'look at [Manichaean texts], to read them and they seem even to be prevented from copying them', Leurini, The Manichaean Church, 85. So also Lim, 'nomen manichaeorum', 155; and see Kevin Coyle, 'What Did Augustine Know About Manichaeism When He Wrote his Two Treatises De Moribus?', in Manichaeism and its Legacy (Leiden: Brill, 2009). However, Johannes van Oort has convincingly shown that Augustine acquired most of his knowledge already during his time as an Auditor, at least in part through his own readings, contesting Coyle's interpretation. Van Oort adduces several passages that show Augustine reading 'books of Mani' ('Young Augustine', 450-56). Moreover, the line Leurini cites from the parable of the writing Auditor does not end there (although the final words are lost); it is, in fact, part of a string of metaphors concerning positive activities that Auditors were requested to do for the Church, and that lifts them out of their lowly state. So for instance, in the same text we find that: 'The Hearer who gives alms to the Elect, is like unto a poor man that presents his daughter to the king; he reaches a position of great honour', Walter B. Henning, 'The Book of the Giants', Bulletin of the School of Oriental and African Studies 11, no. 1 (1943): 63-64. More recently, see Piras, 'The Writing Hearer', 528-29. 
'a catechetical as well as liturgical function'.118 The notions were all present in the Daily prayer, to be prayed 'at least three times a day' according the text found at Kellis, as we have seen. It seems to have provided a list of what its author, i.e. presumably Mani, considered most crucial for adherents, including Auditors, to internalise. It included the primeval war between Light and Darkness, the construction of the world by Light divinities from evil matter, the salvific role of the sun and the moon, the existence of a world soul in which all life takes part, and the need to serve the Elect to be freed from transmigration. This prayer was widely used by adherents. At Kellis, it is further demonstrated by Makarios' exhortation for Matthaios to practice (or write) the 'prostrations' ( $\mathrm{\lambda}$ ICIC), ${ }_{119}^{19}$ and by the discovery that its first few words are scribbled on the board constituting P.Kellis I Gr. 82 and P.Kellis V Copt. $48 .{ }^{120}$ Augustine, in his Confessions, attests to the centrality of this prayer during his time as an Auditor, and it was still in use at the time of al-Nadim and of the Uyghur kingdom in Turfan.

Augustine provides an intriguing example of how notions could be appropriated. Recent scholarship has shown that his engagement with Manichaean ideas was extensive, and lingered after his 'de-conversion.' ${ }^{21} \mathrm{He}$ displays explicit knowledge of more 'esoteric' myths, or mythical imagery. Thus, in his polemical work against the Manichaean bishop Faustus, he describes a well-known psalm sung by the community, called 'the Song of the Lovers'.122 According to Augustine, it depicted the garlanded Father of Lights in the Land of Light, among many identities mountains and sweet air, surrounded by his Twelve Aeons, grouped three by three in four regions, and it described the five sons of the Living Spirit - the Custodian of Splendour, the King of Honour, the Adamas of Light, the King of Glory, and Atlas, - each with his own

\section{P.Kellis VI, 106.}

119 Cf. Brand ('Manichaeans of Kellis', 297), who argues that it should be taken in the sense of 'inflections'. However, the other terms in Makarios list are all texts. Al-Nadim records that the Manichaeans prostrated themselves while praying, and it seems likely that this is the way that proskyneō must be understood in P.Kellis I Gr. 98. Gardner, 'Manichaean Ritual Practice', 253-56; id., "'With a Pure Heart"', 86-87.

120 Iain Gardner, 'P. Kellis 82 and an Unnoticed Record of the Manichaean Daily Prayers', Zeitschrift für Papyrologie und Epigraphik 211 no.1 (2019).

121 For the potentially comprehensive effect that Manichaean concepts of for instance memory had on Augustine, see Johannes van Oort, 'God, Memory, and Beauty: A Manichaean Analysis of Augustine's Confessions, Book 10,1-38', in Augustine and Manichaean Christianity, ed. J. van Oort (Leiden: Brill, 2013).

122 C. Faust. 15.5-6, trans. Roland J. Teske, Answer to Faustus a Manichaean (New York: New City Press, 2007), 189-91. See also Lieu, Manichaeism in the Roman Empire, 134. 
properties. Samuel N. C. Lieu has pointed out that psalms with similar content are found in the Psalm-book. ${ }^{123}$ These divinities were also named in at least one psalm found at Kellis. The usage of 'esoteric' mythological imagery in hymns was clearly widespread, and as Lieu argues, Augustine's ability to recall this imagery likely indicates that they had a mnemonic effect.

Augustine, to be sure, could be a special case. Yet he does describe several key notions as common knowledge. Having gotten a sub-deacon of his see, Victorinus, to confess to being a Manichaean Auditor, he explained in a letter to the bishop of Caesarea in Mauretania that: "They (the Auditors) also adore and pray to the sun and moon with the elect. On the Lord's day they also fast with them, and they believe along with them all the blasphemies because of which the heresy of the Manichees should be detested.' ${ }^{124}$ He goes on to list such 'blasphemies', including the participation of animals in the divine, God's battle and mixture with Darkness, the Elect's purification of Light, and the Light's ascent through the sun and moon. Richard Lim has suggested that while Victorinus admitted to being an Auditor, he did not admit to and probably did not hold these beliefs (despite Augustine's insistence to the contrary), and was not part of any Manichaean group. ${ }^{125}$ However, whatever the case of Victorinus, in light of the Kellis finds there is little reason to doubt that most Auditors were in fact familiar with them.

Thus, even if many details were known mainly to the Elect, and some could vary with time and place, the key notions of the 'Manichaean world' circulated widely. The effort to disseminate them must be seen in relation to a need to defend Elect practice, to furnish it with rationales. The Elect in Egypt, and the Roman Empire more generally, were working to establish religious authority in an environment of much religious competition. Their position as 'holy men' would have to be explained to the laity, and defended against the traditional religious authority of the temples, of the emerging Christian Church, as well as of other 'holy men'. Appeals to the authority of Christ certainly played a part when preaching in Christian environments, but the Elect would have had to differentiate themselves from mainstream Christian teachers in order to justify their specific regime and needs. Persuading their listeners of the validity of their particular 'world' - the primeval dualism, the imprisoned Light, its transmigration, a salvation facilitated by the Elect - were necessary for adherents

\footnotetext{
123 E.g. Psalm 219 (2 Ps. 1-3). See Lieu, Manichaeism in the Roman Empire, 134-35.

124 Augustine, ep. 236 (to Deuterius), trans. Roland J. Teske, Letters 211-270, $1^{*}-29^{*}$ (Epistulae) (New York: New City Press, 2005), 134-35.

125 Lim, 'nomen manichaeorum', 155.
} 
to accept the burdens of almsgiving. They provided narratives within which other ritual acts could be made sense of. ${ }^{126}$ Moreover, they may have resonated with myths already familiar to potential 'converts' - although they could also, at times, come into conflict with the sensibilities of other relatively systematised world-views, such as that of Neoplatonism in the case of Augustine. It is often implied that the Elect simply alluded to their intricate mysteries, 'enticing' Auditors with promises of a total explanation. This is largely based on the experience of Augustine, who expressed much bitterness over that what the Elect had 'served' him was not the explanations he had been promised (or wanted). But we should not generalise from Augustine's polemically shaped narrative of his own 'de-conversion' to that of other adherents, for whom the myths and images of Mani would have continued to hold attraction.

This does not mean that Auditors always responded with great interest to 'lore'. Thorough study of the system of emanations and mythological details was in all likelihood rather uncommon, restricted to literate and enthusiastic adherents, although the discovery of T.Kellis II Copt. 1, describing the aspects of the Third Ambassador, suggests that such were present also at Kellis. But despite the attempts of authorities to initiate Auditors into the Manichaean world, adherents may have considered many aspects irrelevant, harboured reservations, or interpreted the instructions outside the preferred framework of Manichaean authorities - while at the same time continuing to participate in rituals and to identify with as adherents. As discussed in Chapter 5 , individuals juggle many identities, and it is not a given that everyone at Kellis gave their Manichaean one a special saliency, or thought it necessary to internalise all of these ideas. But as BeDuhn stressed, the primary function of ritual language is to reinforce a sense of belonging to a distinct social body. ${ }^{127}$ Even if the ritual and textual practices did not always affect the conscious 'knowledge' or 'beliefs' of participants, it would have had the effect of socialising them into the community of the 'Holy Church'.

In conclusion, the literary texts from Kellis show a high degree of awareness of specifically Manichaean myths and beliefs, and attest to conscious attempts by Manichaean authorities to disseminate such notions among the laity. The degree to which individual adherents engaged with them would certainly vary, as in other comparable religious groups, and we should not imagine that every part of the Manichaean 'theology' reconstructed by modern scholars was

\footnotetext{
126 See e.g. the chapter of the Berlin Kephalaia concerned with the Call and Response (keph. 115), or with the laying on of hands (keph. 9).

127 BeDuhn, The Manichaean Body, 242-44.
} 
known to them. However, key ideas must have become familiar to the laity through texts used in both individual and communal practice, as attested to by the literary and the documentary sources from House 1-3. In turn, such practices functioned to create and reinforce a sense of belonging to a distinctive textual community: the 'Holy Church' of Mani. The laity of Kellis, insofar as they sang the psalms, prayed the prayers, or copied the texts, participated in reproducing a distinctly Manichaean communal identity. 